\title{
Microanatomy of the trophosome region of Paracatenula cf. polyhymnia (Catenulida, Platyhelminthes) and its intracellular symbionts
}

\author{
Nikolaus Leisch • Ulrich Dirks • Harald R. Gruber-Vodicka • \\ Markus Schmid $\cdot$ Wolfgang Sterrer $\cdot$ Jörg A. Ott
}

Received: 13 June 2011/Revised: 11 August 2011/ Accepted: 13 August 2011/Published online: 14 September 2011

(C) The Author(s) 2011. This article is published with open access at Springerlink.com

\begin{abstract}
Marine catenulid platyhelminths of the genus Paracatenula lack mouth, pharynx and gut. They live in a symbiosis with intracellular bacteria which are restricted to the body region posterior to the brain. The symbionthousing cells (bacteriocytes) collectively form the trophosome tissue, which functionally replaces the digestive tract. It constitutes the largest part of the body and is the most important synapomorphy of this group. While some other features of the Paracatenula anatomy have already been analyzed, an in-depth analysis of the trophosome region was missing. Here, we identify and characterize the composition of the trophosome and its surrounding tissue by analyzing series of ultra-thin cross-sections of the species Paracatenula cf. polyhymnia. For the first time, a protonephridium is detected in a Paracatenula species, but it is
\end{abstract}

Communicated by T. Bartolomaeus.

Electronic supplementary material The online version of this article (doi:10.1007/s00435-011-0135-y) contains supplementary material, which is available to authorized users.

N. Leisch $(\bowtie) \cdot$ U. Dirks · H. R. Gruber-Vodicka

J. A. Ott

Department of Marine Biology, University of Vienna,

Althanstraße 14, 1090 Vienna, Austria

e-mail: niko.leisch@gmail.com

M. Schmid

Department of Microbial Ecology, University of Vienna,

Althanstraße 14, 1090 Vienna, Austria

W. Sterrer

Bermuda Aquarium, Natural History Museum and Zoo (BAMZ),

Flatts Village, Bermuda morphologically reduced and most likely not functional. Cells containing needle-like inclusions in the reference species Paracatenula polyhymnia Sterrer and Rieger, 1974 were thought to be sperm, and the inclusions interpreted as the sperm nucleus. Our analysis of similar cells and their inclusions by EDX and Raman microspectroscopy documents an inorganic spicule consisting of a unique magnesium-phosphate compound. Furthermore, we identify the neoblast stem cells located underneath the epidermis. Except for the modifications due to the symbiotic lifestyle and the enigmatic spicule cells, the organization of Paracatenula cf. polyhymnia conforms to that of the Catenulida in all studied aspects. Therefore, this species represents an excellent model system for further studies of host adaptation to an obligate symbiotic lifestyle.

Keywords Platyhelminthes - Symbiosis - Paracatenula . Ultrastructure - Trophosome

\section{Introduction}

Morphological and molecular evidence indicates that the Catenulida are the most basal group of Platyhelminthes (Ehlers 1985; Larsson and Jondelius 2008; Philippe et al. 2011). Most species of the order are limnic, but the Retronectidae were initially reported to be exclusively marine (Sterrer and Rieger 1974) and containing two genera, Retronectes and Paracatenula. Noreña and Faubel (1996) described a third genus-Myoretronectes from a limnic habitat. While Retronectes species and most limnic Catenulida have been reported from tropical to cold temperate regions, the members of the genus Paracatenula have been found only in warm-temperate to tropical regions. All species of the genus Paracatenula lack mouth, pharynx and 
Fig. 1 Habitus of Paracatenula cf. polyhymnia. a Light microscope micrograph, dotted rectangle represents area of serial section. b Phase contrast micrograph of the anterior region. $t r$ trophosome region, $r o$ rostrum, $s p$ spicule, $b a$ bacteria
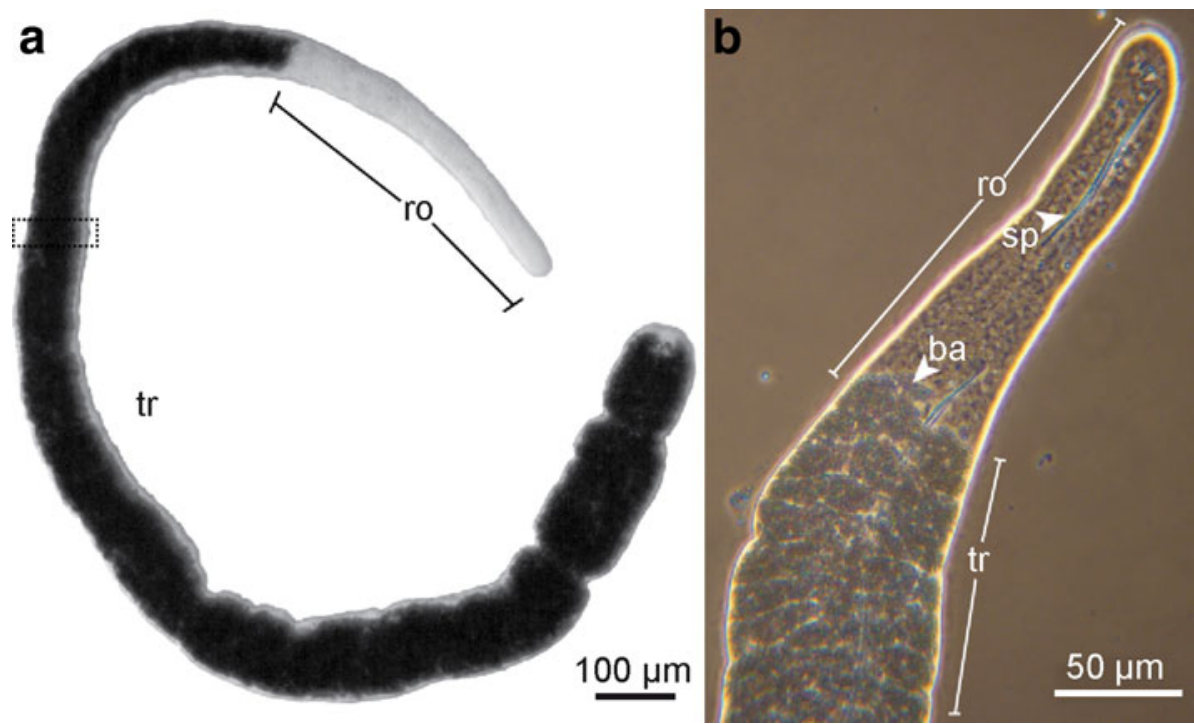

gut (Sterrer and Rieger 1974). Instead, the largest part of the body is made up of a tissue composed of bacteriocytes, cells harboring intracellular bacterial symbionts (Ott et al. 1982). This tissue is called the trophosome (Dirks et al. 2011), in functional analogy to the trophosome found in the mouthless Siboglinidae (Annelida) (Fig. 1). All species of the genus Paracatenula inhabit the interstitial space of shallow-water subtidal sands. In this habitat, chemoautotrophic primary production by prokaryotes oxidizing reduced sulfur compounds plays a vital role comparable to hydrothermal hot vents, cold seeps and whale- and woodfalls. Mutualistic symbioses with sulfur-oxidizing bacteria have been documented from these habitats for many taxa of eukaryotes, including ciliates, nematodes, mollusks and annelids. Most of these show profound morphological adaptations to the symbiotic lifestyle, such as reduction in mouth and gut, specialized symbiont-housing tissues and reduction in excretory organs. The symbionts belong to several different clades in the Alpha-, Gamma- or Epsilonproteobacteria (Dubilier et al. 2008; Gruber-Vodicka et al. 2011). The association between Paracatenula species and the thiotrophic Alphaproteobacteria Candidatus Riegeria likely dates back to the early days of platyhelminth evolution more than 500 million years ago (Gruber-Vodicka et al. 2011). Similar to what has been shown for other meiofaunal hosts of sulfur-oxidizing bacteria, e.g., nematodes (Ott et al. 1991) or gutless oligochaetes (Giere et al. 1991), the animals probably migrate through the redox potential gradient in the top 5-15 cm layer of the sediment and thus could provide their symbionts with both sulfide and electron acceptors such as nitrate or oxygen. In endosymbiotic associations, such as in the genus Paracatenula, the host additionally provides a sheltered and stable environment to its symbionts. In return, the symbionts likely satisfy most or even all of the nutritional demands of the host.

Platyhelminthes are known for their unique system of totipotent stem cells - the neoblasts_-from which all cells arise and which are the only cells showing mitotic activity (Ladurner et al. 2000; Peter et al. 2004). On the ultrastructural level, they can be identified by the following structures: (1) a highly active nucleus displaying a checkerboard pattern, (2) many mitochondria, (3) free ribosomes and (4) chromatoid bodies (Hori 1982). The chromatoid bodies are electron-dense structures that can be found close to the nuclear envelope and mitochondria. They contain RNA and proteins and are essential for the cytodifferentiation process (Auladell et al. 1993). The ultrastructural investigation of the neoblast also gave the opportunity to add to the knowledge of the anatomy of this exceptional representative of the Catenulids, a group that is less well studied than many other platyhelminth taxa (Bedini and Papi 1974; Ehlers 1985; Hooge 2001; Moraczweski 1981; Rieger et al. 1991; Rohde 2001).

While several studied features of Paracatenula, such as muscle arrangement (Hooge 2001) or brain organization (Sterrer and Rieger 1974), are typical for Catenulida, the synapomorphy of this genus is the lack of a digestive tract and its functional replacement by the trophosome tissue. We therefore focused on this region in Paracatenula cf. polyhymnia, using serial-sectioning-based transmission electron microscopic reconstructions, scanning electron microscopy, together with energy dispersive X-ray analysis and Raman microspectroscopy techniques. We characterized the tissue composition and resolved enigmatic structures that are unique to these worms, such as the spiculeshaped inclusions, previously regarded as sperm, which are in fact of mineral nature ("sp" in Fig. 1b). 


\section{Materials and methods}

Specimens were collected during two field trips (October 2009, June 2010) in Dahab, Egypt. Sampling took place in "Eel Garden" (28 $30^{\prime} 19.97^{\prime \prime} \mathrm{N}, 34^{\circ} 31^{\prime} 18.52^{\prime \prime} \mathrm{E} ; 8 \mathrm{~m}$ depth) and "Napoleon Reef" $\left(28^{\circ} 28^{\prime} 13.83^{\prime \prime} \mathrm{N}, 34^{\circ} 30^{\prime} 32.51^{\prime \prime} \mathrm{E} ; 1 \mathrm{~m}\right.$ depth). Specimens were extracted from the fine to medium sand by shaking it with filtered seawater and decanting the supernatant through a $32-\mu \mathrm{m}$ mesh sieve. The content of the net was transferred into a petri dish, and approximately 200 specimens were sorted by morphological features under a dissecting microscope. Paracatenula cf. polyhymnia was identified by the presence of spicules similar to those of Paracatenula polyhymnia, reported from the Western Atlantic (Sterrer and Rieger 1974). Reference material for P. cf. polyhymnia has been deposited in the Natural History Museum Vienna under the numbers NHM Wien/Vienna Ev varia 20.109 and NHM Wien/Vienna Ev varia 20.110.

\section{Ultrastructure}

Specimens were pre-fixed with $2.5 \%$ glutaraldehyde in a $0.1 \mathrm{M}$ sodium cacodylate buffer for $12-16 \mathrm{~h}$ at $4^{\circ} \mathrm{C}$, rinsed three times and stored in $0.1 \mathrm{M}$ sodium cacodylate buffer until post-fixation with $1 \%$ osmium tetroxide $\left(2 \mathrm{~h}\right.$ at $\left.4^{\circ}\right)$. Specimens were then dehydrated in a graded alcohol series and embedded in Low Viscosity Resin (Agar Scientific) with acetonitrile as the intermediate solvent. The resin was polymerized at $40^{\circ} \mathrm{C}$ for $1 \mathrm{~h}$ followed by $48 \mathrm{~h}$ at $60^{\circ} \mathrm{C}$. Ultrathin sections $(70 \mathrm{~nm}$ ) were cut on an Ultracut $\mathrm{S}$ (Leica) and mounted on formvar-coated copper slot grids (Agar Scientific). The sections were stained with $0.5 \%$ uranyl acetate (Leica) for $20 \mathrm{~min}$ and with $2 \%$ lead citrate (Leica) for $6 \mathrm{~min}$. Sections were viewed on a Zeiss EM-902, and images were recorded with an Olympus SharpEye camera system using the AnalySIS 5.0 program. Images were merged, and measurements were taken with Adobe Photoshop CS 4. Cross-sections were digitized in Adobe Illustrator CS 4 . All area calculations were performed with ImageJ (ver 1.42q). Statistics were done in Microsoft Excel 2007.

\section{SEM, EDX and Raman microspectroscopy}

For the analysis of complete spicules, a specimen was macerated on a microscope slide by adding double distilled water and gently pumping with the coverslip until the spicules were released from the worm tissue. The spicules were then transferred to SEM stubs with carbon foil and either gold-coated with a sputter coater (AGAR B7340) for SEM analysis or carbon-coated (PAAR EPA 101) for EDX analysis. Samples were analyzed with a Philips XL20, images taken with the Microscope Control program (Ver. 7.00, FEI) and EDX spectra were obtained with the EDAX
Genesis software (Ver. 5.11 EDAX). Readings from the carbon-coated stub served as a signal background for our measurements. For Raman microspectroscopy, only individuals that had not been relaxed with magnesium chloride were used. Both semi-thin sections $(2.5 \mu \mathrm{m})$ of resinembedded specimens and complete spicules were mounted on a calcium fluoride slide, and analysis was performed with a LabRAM HR800 confocal Raman microscope (Horiba Jobin-Yvon, Bensheim, Germany), utilizing a 532-nm Nd: YAG laser $(50 \mathrm{~mW})$. Spicules were selected using a $50 \times$ objective, and the signal was acquired over a period of $5 \mathrm{~s}$ using a D0.6 intensity filter $(25 \%$ laser intensity). The pinhole of the Peltier-cooled CCD detector was adjusted to $250 \mu \mathrm{m}$ (optical slice $4.6 \mu \mathrm{m}$ ). Spectra were measured between 300 and $2,000 \mathrm{~cm}^{-1}$, the range where the compounds identified with the EDX showed the most characteristic peaks. The spectra were acquired, baseline-corrected and normalized with the Labspec software 5.25.15 (Jobin-Yvon). To verify the calibration, the known line of a silicon Raman reference $\left(520 \mathrm{~cm}^{-1}\right)$ was periodically checked. For further peak determination and calculation, the data were exported to Microsoft Excel. Various commercially available phosphates as well as magnesium pyrophosphate synthesized by heating magnesium phosphate to $700^{\circ}$ for $24 \mathrm{~h}$ were measured using the same settings.

Fluorescent staining of whole mounts

Specimens were relaxed with a magnesium chloride solution isotonic to seawater, fixed for $12 \mathrm{~h}$ in $4 \%$ formaldehyde at $4^{\circ} \mathrm{C}$, rinsed in phosphate-buffered saline (PBS) and stored in PBS at $4^{\circ} \mathrm{C}$ for transport. The specimens were washed and permeabilized with PBS containing 0.2\% Triton X-100 (PBS-T), followed by staining for $30 \mathrm{~min}$ with phalloidin-Alexa 568 diluted 1:200 in PBS-T and 3 washing steps in PBS as well as a DAPI staining for $5 \mathrm{~min}$. For tubulin staining, the fixed animals were transferred into PBS-T and digested for $6 \mathrm{~min}$ at room temperature in PBS$\mathrm{T}$ containing $0.1 \mathrm{mg} / \mathrm{ml}$ proteinase $\mathrm{K}$. Digestion was stopped by adding $2 \mathrm{~N}$ hydrochloric acid. Animals were washed in PBS-T and blocked in BSA-T $(1.5 \%$ bovine serum albumin (BSA) plus $0.2 \%$ Triton $\mathrm{X}-100$ ) for $30 \mathrm{~min}$ and afterward stained overnight at $4{ }^{\circ} \mathrm{C}$ with an antibody against acetylated tubulin produced in mouse (Sigma Aldrich, Austria) 1:1,000 diluted in BSA-T. After three washing steps in PBS-T, an Alexa 547-conjugated secondary antibody was applied for $1 \mathrm{~h}$ at room temperature at a 1:300 dilution in BSA-T. The specimens were mounted on slides in Vectashield (Vector Laboratories), and the slides were examined and photographed with an epifluorescence microscope (Zeiss Axio Imager), or scanned with a confocal laser scanning microscope (Zeiss LSM 510). 


\section{Results}

The ultrastructure of the trophosome region of Paracatenula cf. polyhymnia was analyzed in both cross- and longitudinal sections of several specimens. To provide an overview of the tissue composition of the trophosome, whole cross-sections of this body region (Figs. 1,2) as well as high-magnification serial sections of the body wall were digitized and analyzed (Fig. 3).
Tissue composition of the trophosome region

Since the trophosome region is homogenous over its whole length, we used serial cross-sections of a $30 \mu \mathrm{m}$ long part as representative for determining tissue composition. Three cross-sections at 0,15 and $30 \mu \mathrm{m}$ were digitized, and the percentage of each tissue calculated (Table 1). Under the assumption that the relative contributions do not change along the extent of the region, percent area in the

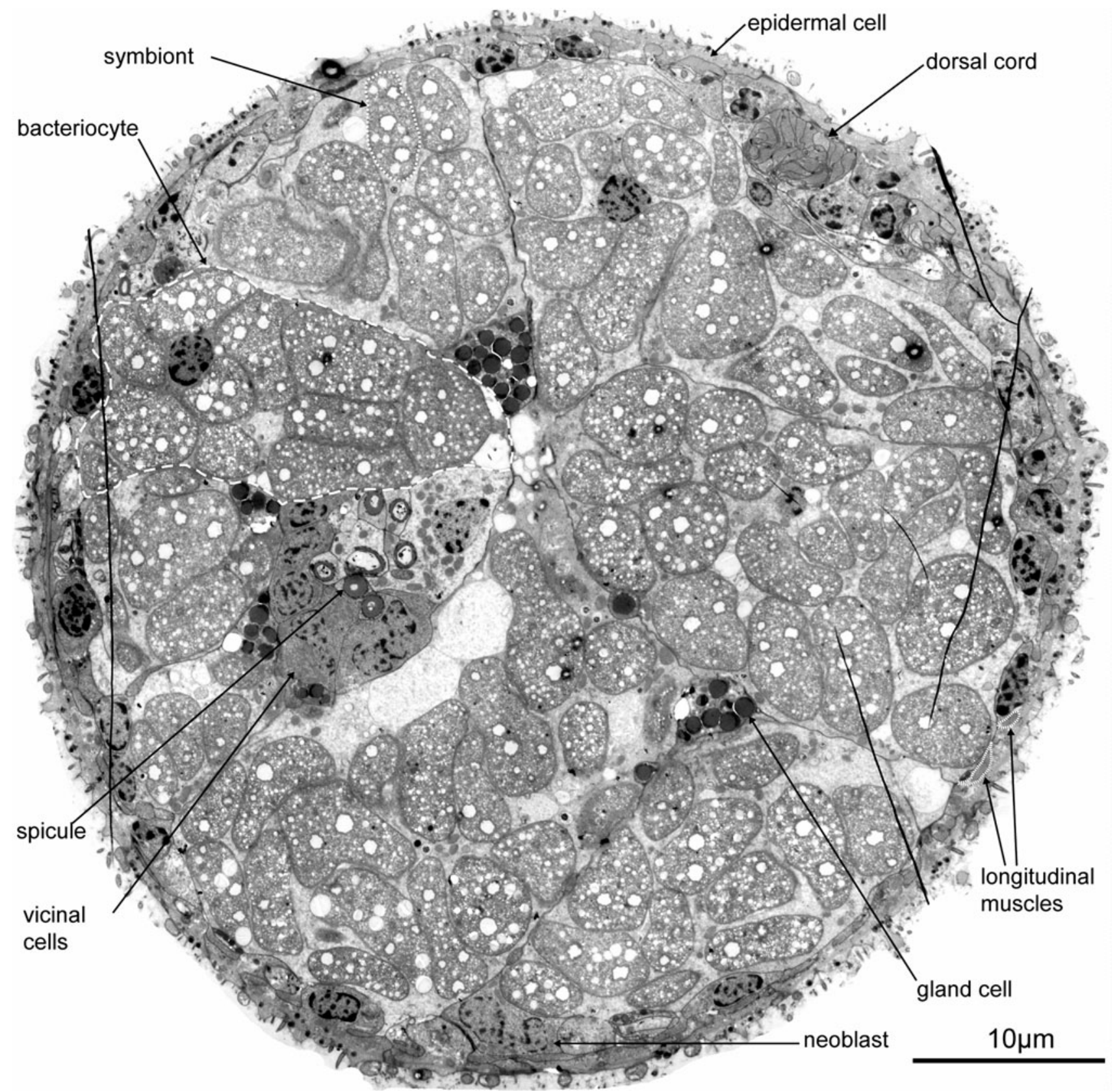

Fig. 2 TEM micrograph of a complete cross-section of Paracatenula cf. polyhymnia, dashed line indicates bacteriocyte, dotted line indicates single symbiont and striped line indicates longitudinal muscles 
Table 1 Percentages of area occupied in the cross-section by the different tissue and cell types in Paracatenula cf. polyhymnia

\begin{tabular}{lll}
\hline Tissue and cell types & \% of total & SD \\
\hline Epidermis and subepidermal tissue & 22 & 0.5 \\
Trophosome & 79 & 0.6 \\
Bacteriocytes (including bacteria) $_{\text {Bacteria }^{\text {a }}}$ & 73 & 0.5 \\
Spicule cells & 52 & 0.6 \\
Glands & 4 & 0.3 \\
\hline
\end{tabular}

${ }^{a}$ Gruber-Vodicka et al. (2011)

cross-section is used as an estimate of percent volume in the respective body region. The following tissues were distinguished: (1) Epidermis; (2) Subepidermal tissue including nerves, muscle cells, neoblasts and a protonephridium; (3) Trophosome including the bacteriocytes, spicule cells and their associated cells and glands (supplementary 1).

\section{Epidermis}

The epidermis is multi-ciliated and consists of a single cell layer (Fig. 3a). The cells are $15.6 \pm 2.3 \mu \mathrm{m}(n=6)$ wide, $3.2 \pm 0.9 \mu \mathrm{m}(n=9)$ long and $2.9 \pm 0.5 \mu \mathrm{m}(n=10)$ thick. In average, $22.8 \pm 3.3(n=6)$ epithelial cells were found per cross-section. The epidermis cells exhibit an apico-basal polarity, with the apical part bearing a glycocalyx and the cilia while the nucleus is located in the basal part which is deeply sunken into the underlying tissues. The cilia show a $9 \times 2+2$ microtubule pattern. There is no basement membrane; however, a terminal web with an average thickness of $175 \pm 50 \mathrm{~nm}(n=15) \mathrm{nm}$ is present. The cells are interdigitated with their neighboring cells and linked via apical zonulae adhaerentes followed by septate junctions.

\section{Subepidermal tissue}

\section{Musculature}

The musculature consists of a net of very fine circular and slightly thicker longitudinal muscles (Fig. 4) embedded between the basal and the apical part of the epidermal cell, with the circular fibers lying in a more distal position (Fig. 3b). The circular muscles have a diameter of $233 \pm$ $35 \mathrm{~nm}(n=9)$.

The longitudinal musculature can be divided into two types: (1) Single muscle cells that create a net-like arrangement underneath the epidermis. The myofilament-containing portion is square or round in cross-section, measuring $2 \pm 0.7 \mu \mathrm{m} \quad(n=20) \times 0.5 \pm 0.1 \mu \mathrm{m} \quad(n=20)$. Thin extensions devoid of filaments connect to other muscle cells or serve as sarconeural junctions to the nerves (Fig. 3c). Per cross-section $45 \pm 5(n=7)$ muscle cells were found. (2) An aggregation of longitudinal muscles that constitute a structure termed the "dorsal cord" by Sterrer and Rieger (1974) stretches all the way through the trophosome (Fig. 3d). It consists of 22-25 muscle cells (mean $23.4 \pm 1.2$, $n=7$ ) and makes up roughly $19 \%$ of the longitudinal muscles in a cross-section. The individual cells show long extensions, devoid of myosin filaments, connecting to a large nerve, which is embedded in the extensions.

\section{Nerves}

A larger nerve (diameter $1.45 \pm 0.15 \mu \mathrm{m}, n=3$ ) extends along the anterior-posterior (A-P) axis as part of the dorsal cord (Fig. 3d). Smaller axons with a rectangular shape in cross-sections $(2.30 \pm 0.42 \mu \mathrm{m} \times 0.37 \pm 0.17 \mu \mathrm{m})$ can be found in tight association with the longitudinal musculature (Fig. 3c).

\section{Protonephridium}

Over the length of the ultra-thin series, one unpaired biciliated protonephridium could be located beneath the dorsal cord (Fig. 5). It stretches $4.4 \mu \mathrm{m}$ along the A-P axis, and the cilia extend for $3.4 \mu \mathrm{m}$, but neither a weir nor a canal cell could be found.

\section{Neoblasts}

Stem cells (neoblasts) are located directly underneath the epidermis. They are small and tightly packed with cell organelles, including chromatoid bodies (Fig. 6a). The cells are $8.3 \pm 2.0 \mu \mathrm{m}(n=10) \times 5.6 \pm 1.0 \mu \mathrm{m}(n=10)$ in size and stretching $4.2 \pm 1.0 \mu \mathrm{m}(n=3)$ along the A-P axis.

\section{Trophosome}

\section{Bacteriocytes}

In cross-sections, $73.0 \% \pm 0.5(n=3)$ of the area is taken up by bacteriocytes (including the bacteria). Per crosssection $10.7 \pm 1.7(n=3)$ bacteriocytes were found. A single bacteriocyte can occupy up to $21 \%$ of the crosssection (Fig. 6b). The cytosol of the bacteriocyte is clear except for few mitochondria and electron translucent vesicles. Up to $71 \%$ of the area of a single bacteriocyte can be occupied by the bacteria.

\section{Glands}

Small cells, interpreted as glands, are situated between the bacteriocytes and in the vicinity of the spicule cells (Fig. 6c). These glands appear highly variable in shape, 

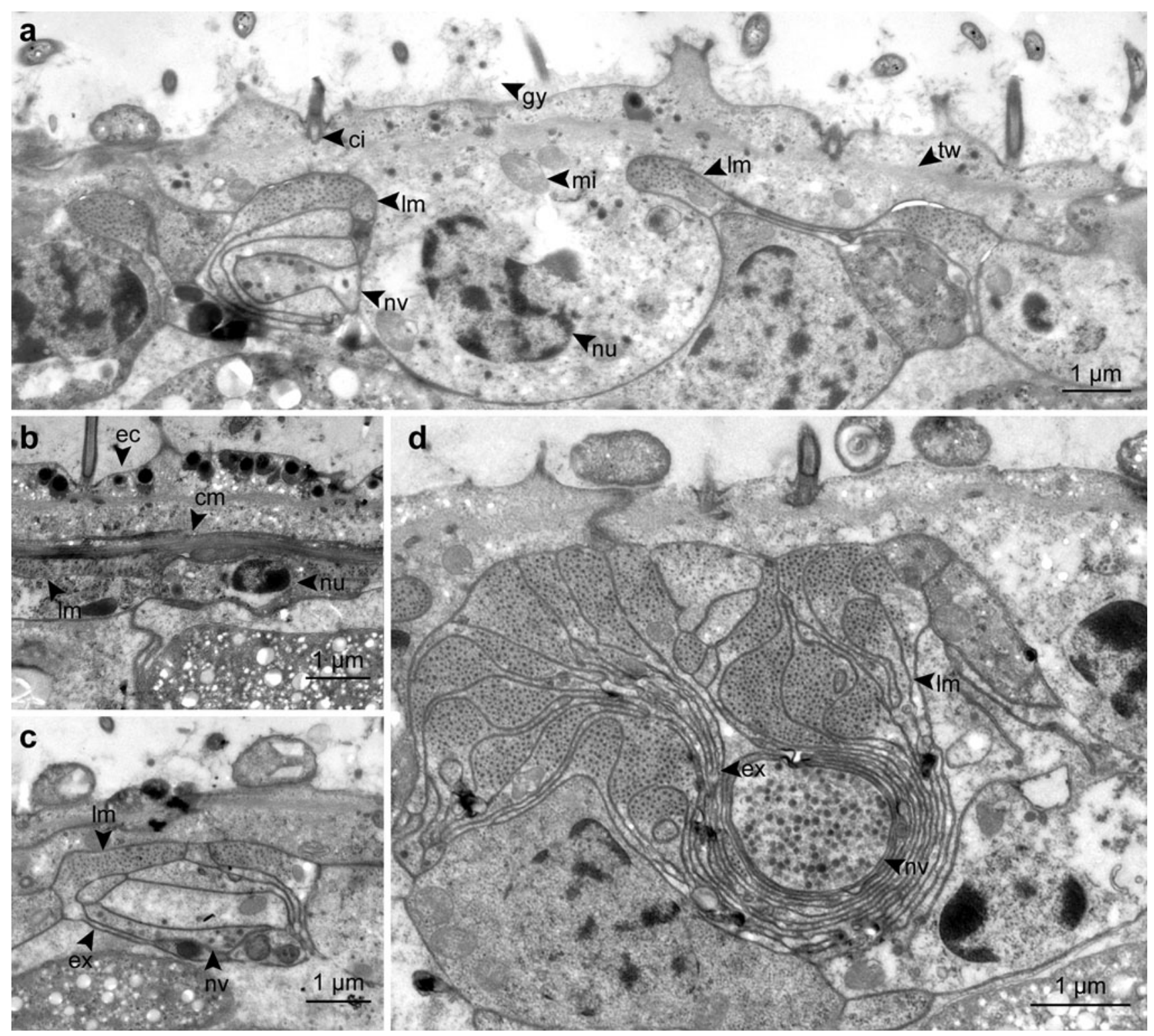

Fig. 3 Detailed TEM micrographs of the body wall, showing epidermal cells, muscles, nerves and the dorsal cord in cross-sections. a Cross-section of a epidermal cell. b Circular muscles below the epidermis. c Nerve cell associated with longitudinal musculature.

ranging in diameter between 4 and $6 \mu \mathrm{m}$. The cells are full of vacuoles filled with an electron-dense material that appeared brittle during sectioning. They have an active nucleus and few mitochondria.

\section{Spicule cells}

Cells, each containing one spicule, are arranged in loose groups of two to six along the A-P axis of the body (Fig. 7a). They are mostly situated close to the center of the individual, among the bacteriocytes. In cross-sections, they have a round shape with a diameter of $2-3 \mu \mathrm{m}$, their sparse cytosol is clear and they have a small nucleus and few mitochondria. d Cross-section of the dorsal cord. $\mathrm{cm}$ circular muscle, $\mathrm{ci}$ cilium, ec epidermis cell, ex extension, gy glycocalyx, $l m$ longitudinal muscle, $m i$ mitochondrion, $n u$ nucleus, $n v$ nerve cell with vesicles, $t w$ terminal web

The spicules are angled, ranging in length between 20 and $50 \mu \mathrm{m}$ (mean $43.6 \mu \mathrm{m} \pm 6.9, n=10$ ), with a diameter of $1 \pm 0.1 \mu \mathrm{m}(n=3)$. The two arms include an angle of $164^{\circ} \pm 1.9(n=3)$. Four to seven cells with a darker cytosol are always in the vicinity of the spicule cells ("vicinal cells"). They have a highly active nucleus and many mitochondria, but their function is still unknown. In SEM, the surface of the extracted spicules appears smooth, except for the inner edge which is jagged like a saw (Fig. 7b). Ultra-thin sections show that the spicule is a mineralized structure, with no indication of organic matter. It is surrounded by the spicule sheath, which consists of an electron-dense layer, which is in turn surrounded by a 

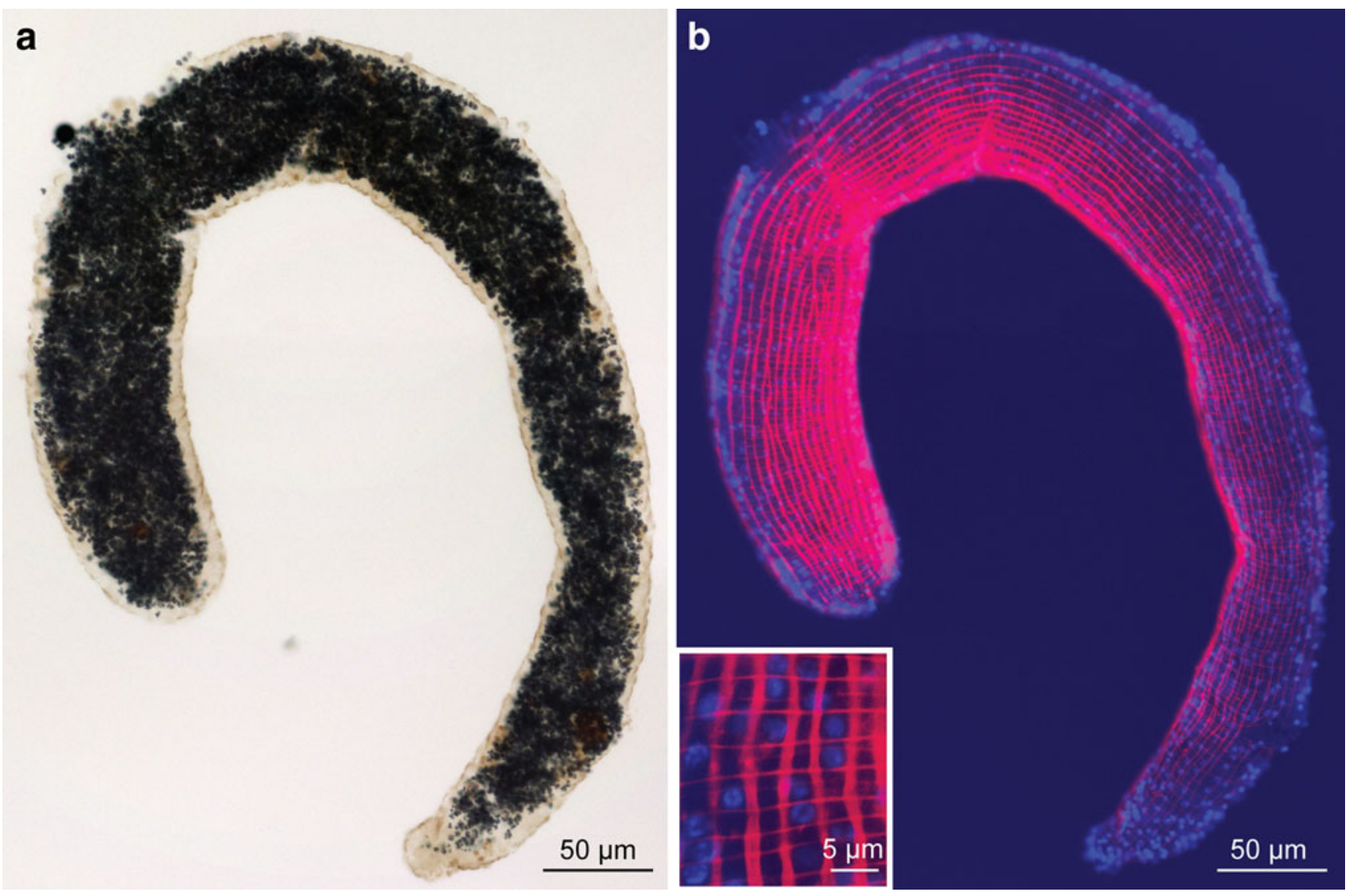

Fig. 4 Phalloidin staining of a trophosome fragment of Paracatenula c.f. polyhymnia a Light micrograph and $\mathbf{b}$ confocal projection of F-actin fluorescently labeled with phalloidin. Insert: detail magnified. red phalloidin, blue DAPI staining of the epidermal nuclei

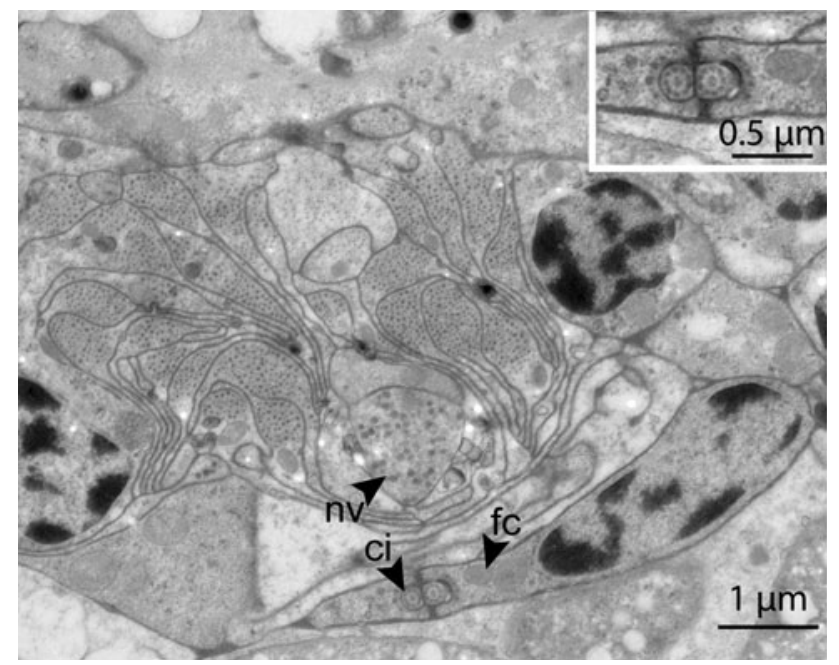

Fig. 5 TEM micrograph of a cross-section of a protonephridium, located underneath the dorsal cord. Insert: Detail of the cilia. $c i$ cilium, $f c$ flame cell, $n v$ nerve cell

basket-style layer of microtubules (Fig. 7c, supplementary 2). We also observed spicule cells without a mineralized core, consisting only of the spicule sheath (Fig. 7a).
EDX measurements were taken in three positions: both tips and the center. The analysis shows strong peaks of carbon, oxygen, phosphorus, magnesium and small peaks of sodium and sulfur (Fig. 8). Both $\mathrm{Na}$ and $\mathrm{S}$ were also present in the measurements of the carbon stub (supplementary 3 ) and are remains of the water transferred with the specimen. Uncoated spicules were further analyzed with a Raman microscope to characterize the molecular structure (Fig. 9). The Raman spectrum of the spicule shows the strongest peak at $1,061 \mathrm{~cm}^{-1}$, which correlates very well with the main peak of the $\mathrm{P}-\mathrm{O}$ band (indicated by the red line in Fig. 9) of Magnesium pyrophosphate $\left(\mathrm{MgP}_{2} \mathrm{O}_{7}\right)$ (Cornilsen and Condrate 1977). Additionally, there are two small peaks between 1,300 and $1,500 \mathrm{~cm}^{-1}$, which are absent in the spectrum of purified magnesium pyrophosphate.

\section{Discussion}

Epidermis, muscles, protonephridia and neoblasts

The epidermis is catenulid specific, showing the sunken nucleus flanked by longitudinal muscles and lacking a 

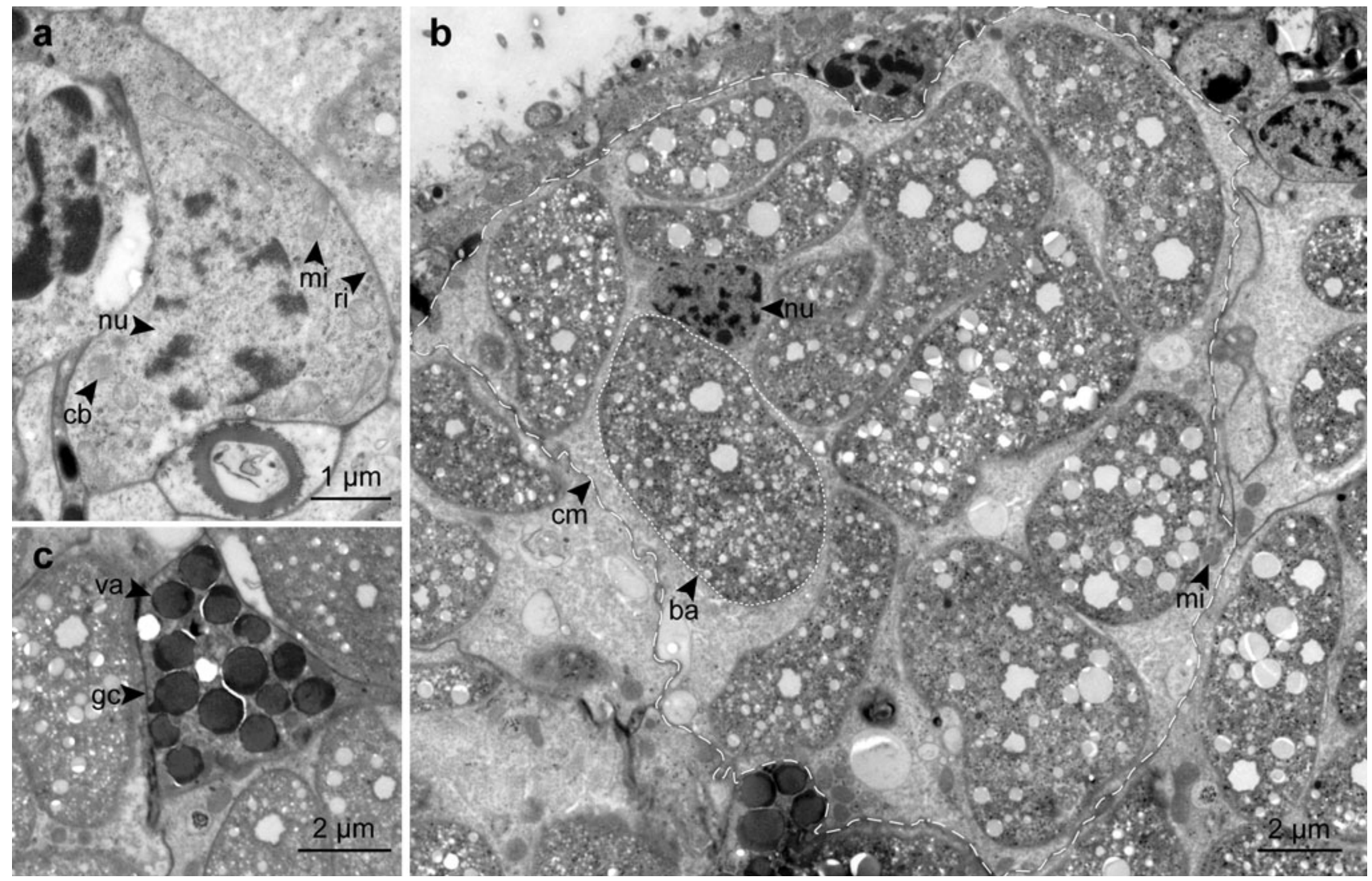

Fig. 6 TEM micrographs of different cell types on a cross-section. a Neoblast. b Bacteriocyte, dashed line indicates bacteriocyte, dotted line indicates single symbiont. c Gland cell. $b a$ bacteria, $c b$ chromatoid body, $\mathrm{cm}$ cell membrane, $g c$ gland cell, $m i$ mitochondrion, $n u$ nucleus, $r i$ free ribosome, $v a$ vacuole

nerve- the contractile element allowing the worms to coil tightly.

Because of their small size and indistinct nature, cyrtocytes cannot be detected by light microscopy and Sterrer and Rieger (1974) assumed they were absent. We were, however, able to identify a single cyrtocyte in our electron microscopical material. It is situated dorsally and has the characteristic bi-ciliation that is typical for the catenulid cyrtocyte (Ehlers 1985). We were also able to locate a protonephridium in Paracatenula galateia Dirks, Gruber, Leisch, Sterrer \& Ott, 2011 (unpublished observation) in the same position as the one in $P$. cf. polyhymnia. The cyrtocyte resembles that of Retronectes thalia Sterrer \& Rieger, 1974 (Rieger 1981). However, in both species, the cell has no weir region and no protonephridial duct, and no connection to a protonephridial pore could be found. We propose two non-mutually exclusive hypotheses for this:

1. Protonephridia are needed for osmoregulation in Platyhelminthes. Retronectidae are thought to have evolved from freshwater catenulids that invaded marine habitats secondarily (Larsson and Jondelius 2008). As there is less osmotic stress in seawater 

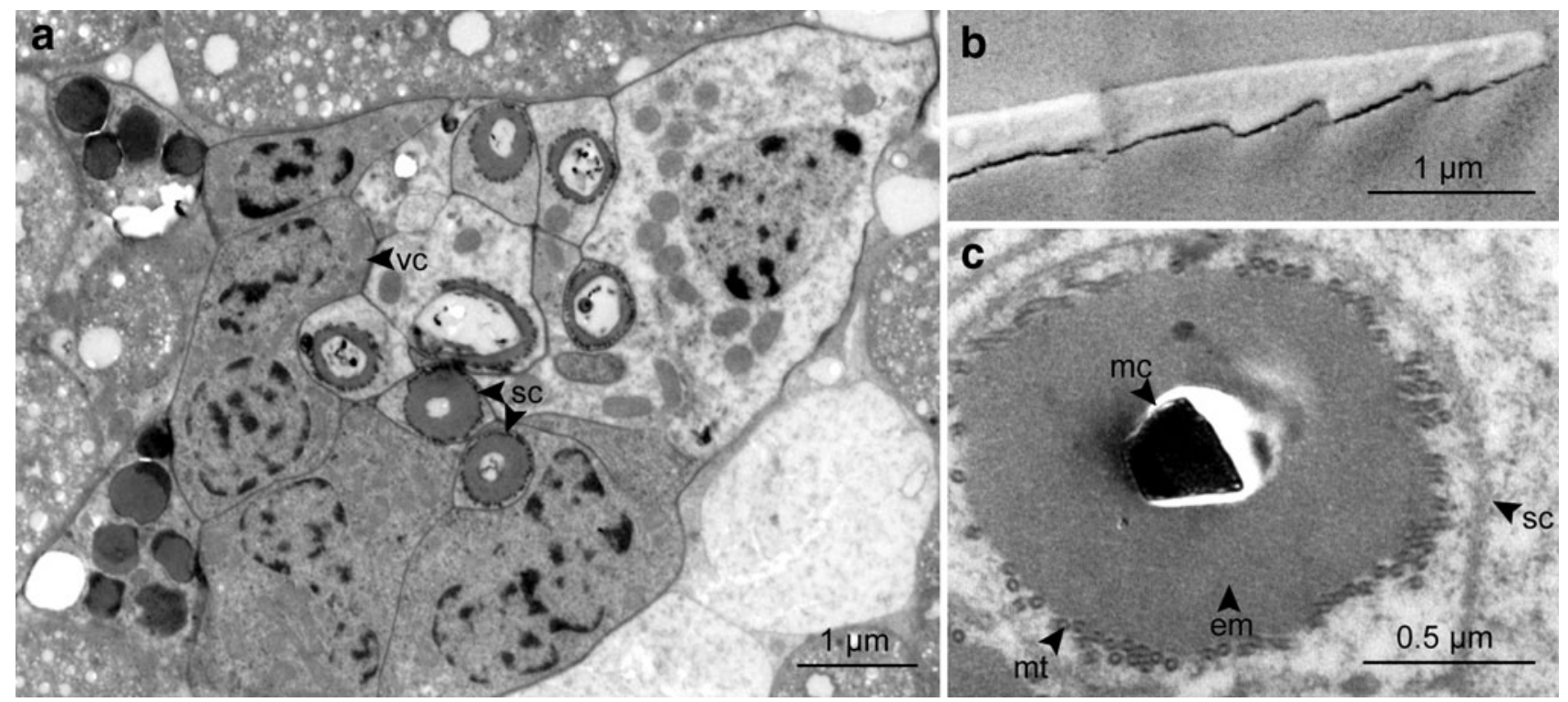

Fig. 7 Micrographs of spicule cells embedded in the trophosome tissue. a Overview of seven spicule cells and associated cells, TEM micrograph. b Tip of the spicule, SEM micrograph. $\mathbf{c}$ Cross-section of

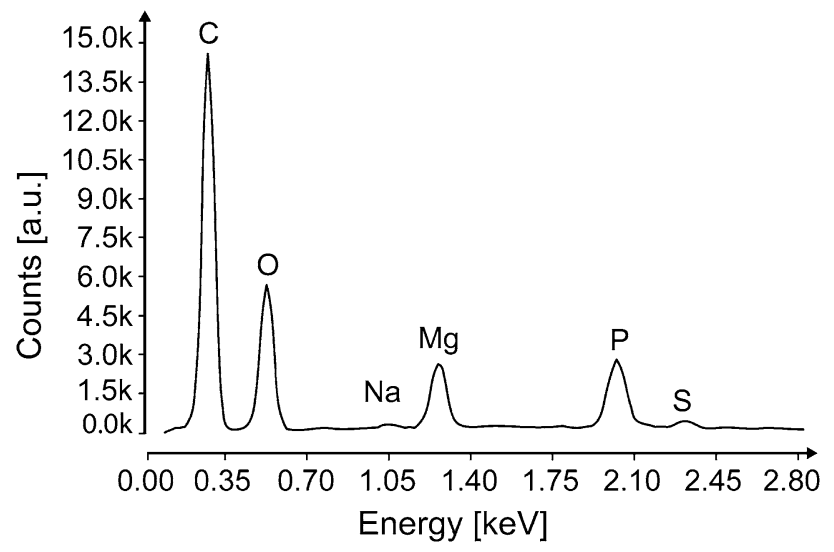

Fig. 8 EDX spectrum of the spicule (All peaks indicate K-Alpha peaks)

compared with freshwater, the protonephridium might have become obsolete and is thus reduced but not yet lost.

2. Nephridial organs remove waste products including nitrogenous compounds. In the mouthless symbiotic nematode Astomonema jenneri Ott, Rieger, Rieger \& Enderes, 1982, no excretory organs were found (Ott et al. 1982). The loss/lack of excretory organs is also known for the gutless oligochaete species of the genus Olavius (Giere 1996). Here, the symbionts could serve for recycling of nitrogen for the host and excretory organs could become reduced or obsolete (Woyke et al. 2006). Similarly, it has been proposed for the symbiotic Siboglinidae species that the bacterial symbionts in the trophosome partially take over the spicule cell, TEM micrograph. em electron-dense material, $m c$ mineralized core, $m t$ microtubules, $s c$ spicule cell, $v c$ vicinal cell

function of the nephridia (Southward et al. 2005). For the same reasons, the protonephridia of $P$. cf. polyhymnia may have become obsolete and are therefore reduced.

We found all the ultrastructural features of the typical platyhelminth neoblast (active nucleus, many free ribosomes and mitochondria) including the chromatoid bodies, a specific neoblast organelle. In the basal rhabditophoran platyhelminth model organism Macrostomum lignano Ladurner, Schärer, Salvenmoser \& Rieger, 2005, Bode et al. (2006) showed that there are two different pools of somatic neoblasts, a mesodermal one located below the epidermis and a gastrodermal one, and in addition two reproductive ones. In $P$. cf. polyhymnia, we found neoblasts only in association with the epidermis. However, the vicinal cells show indications that they might be neoblasts (e.g., chromatin pattern, cell organelles) and could represent either gastrodermal or reproductive neoblasts. Comparative studies of the stem cell system in Catenulida with and without gut will show if multiple sets of neoblasts are a synapomorphy of the Rhabditophora or a plesiomorphic feature of all Platyhelminthes that has been lost in Paracatenula.

\section{Trophosome and spicule cells}

The bacteria in Paracatenula species occupy more volume of the symbiotic consortium than in all animal/bacteria symbioses described so far (Gruber-Vodicka et al. 2011). Of all three Paracatenula species investigated, $P$. cf. 


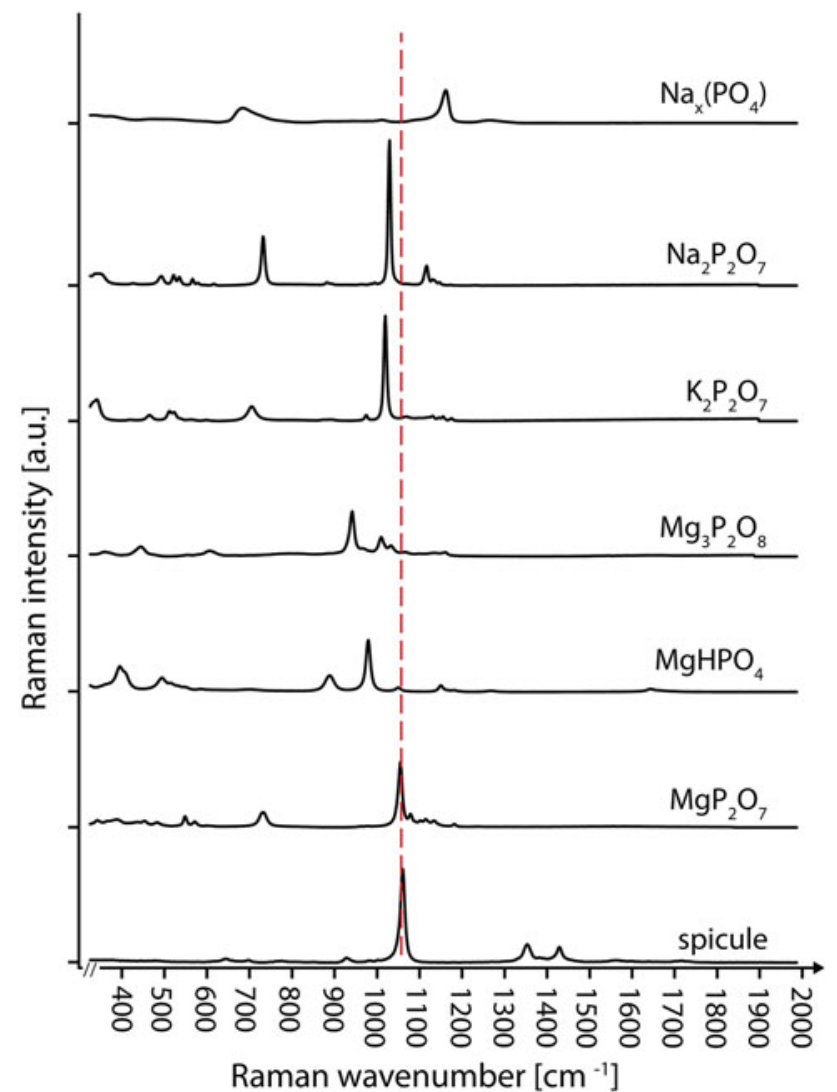

Fig. 9 Baseline corrected and normalized mean Raman spectrographs of different phosphates and the spicule

polyhymnia shows the highest proportion of symbiotic bacteria (Table 1).

Species descriptions of the genus Paracatenula rely on cells with inclusions as important characters to distinguish species (Sterrer and Rieger 1974; Dirks et al. 2011) due to the paucity of morphological characters. Based on observations suggesting spermatogenesis in two species, they were interpreted to be modified sperm and the needleshaped inclusions of $P$. polyhymnia to be condensed sperm nuclei (Sterrer and Rieger 1974). We cannot exclude the possibility that the spicules in $P$. cf. polyhymnia are evolutionary derived from sperm, although for the following reasons, it is unlikely that they have this function in their present form. (1) The inclusion is of mineral nature, and the nucleus next to the mineralized core shows no signs of condensation, as would be expected in sperm. (2) No structures resembling gonads or stages of spermatogenesis could be found. Furthermore, the spicules are evenly scattered throughout the body indicating that there is no common place of origin. (3) No structures, except for the microtubules surrounding the spicule, conveying any form of motility to the cells could be detected.

Localization of gonads and screening for the expression of germline-specific genes could be used to decipher any potential relationship of these enigmatic structures to sexual reproduction. A possible other function could be defense against predators. Superficially, the spicule cells resemble extrusomes such as sagittocysts, but in contrast to Convolutriloba longifissura Bartolomaeus \& Balzer, 1997 (Gschwentner et al. 1999), P. cf. polyhymnia has no muscles for ejection. Furthermore, pyrophosphate is a highenergy compound and is involved in both storage and utilization of energy in microorganisms (Kulaev and Vagabov 1983). This could indicate that the spicules may also have a storage function which would be unique for animals.

Acknowledgments The authors thank the staff of the Department of Ultrastructure Research, University of Vienna, for all the practical help. We thank the Department of Microbial Ecology for the use of the Raman microscope. We also thank Willi Salvenmoser, University of Innsbruck, for his help on the neoblast analysis and Silvia Bulgheresi, University of Vienna, for helpful comments. This work was supported by the Austrian Science Fund (FWF) project 20394-B03 (NL, UD, HGV and JO) and was partially funded by the University of Vienna within the framework of short-term grants.

Open Access This article is distributed under the terms of the Creative Commons Attribution Noncommercial License which permits any noncommercial use, distribution, and reproduction in any medium, provided the original author(s) and source are credited.

\section{References}

Auladell C, Garcia-Valero J, Baguñà J (1993) Ultrastructural localization of RNA in the chromatoid bodies of undifferentiated cells (neoblasts) in planarians by the RNase-gold complex technique. J Morphol 216(3):319-326. doi:10.1002/jmor.1052160307

Bedini C, Papi F (1974) Fine structure of the turbellarian epidermis. In: Riser N, Morse M (eds) Biology of the turbellaria. McGrawHill, New York

Bode A, Salvenmoser W, Nimeth K, Mahlknecht M, Adamski Z, Rieger R, Peter R, Ladurner P (2006) Immunogold-labeled S-phase neoblasts, total neoblast number, their distribution, and evidence for arrested neoblasts in Macrostomum lignano (Platyhelminthes, Rhabditophora). Cell Tissue Res 325(3):577-587. doi:10.1007/s00441-006-0196-2

Cornilsen BC, Condrate RA (1977) The vibrational spectra of magnesium pyrophosphate polymorphs. J Phys Chem Solids 38(12):1327-1332. doi:10.1016/0022-3697(77)90003-8

Dirks U, Gruber-Vodicka HR, Leisch N, Sterrer W, Ott JA (2011) A new species of symbiotic flatworms, Paracatenula galateia sp. nov. (Platyhelminthes: Catenulida: Retronectidae) from Belize (Central America). Mar Biol Res. doi:10.1080/17451000.2011.574880

Dubilier N, Bergin C, Lott C (2008) Symbiotic diversity in marine animals: the art of harnessing chemosynthesis. Nat Rev Micro 6(10):725-740

Ehlers U (1985) Das phylogenetische System der Plathelminthes. Fischer Verlag, Stuttgart

Giere O (1996) Bacterial endosymbiosis in marine littoral worms. In: Uiblein F, Ott JA, Stachowitsch M (eds) Deep sea and extreme shallow-water habitats: affinities and adaptations, vol 11. Biosystematics and Ecology Series. Austrian Academy of Sciences Press, Vienna, pp 353-368 
Giere O, Conway N, Gastrock G, Schmidt C (1991) "Regulation" of gutless annelid ecology by endosymbiotic bacteria. Mar Ecol Prog Ser 68(3):287-299

Gruber-Vodicka HR, Dirks U, Leisch N, Baranyi C, Stoecker K, Bulgheresi S, Heindl NR, Horn M, Lott C, Loy A, Wagner M, Ott JA (2011) Paracatenula, an ancient symbiosis between thiotrophic Alphaproteobacteria and catenulid flatworms. Proc Natl Acad Sci USA. doi:10.1073/pnas.1105347108

Gschwentner R, Ladurner P, Salvenmoser W, Rieger R, Tyler S (1999) Fine structure and evolutionary significance of sagittocysts of Convolutriloba longifissura (Acoela, Platyhelminthes). Invertebr Biol 188(4):332-345

Hooge MD (2001) Evolution of body-wall musculature in the Platyhelminthes (Acoelomorpha, Catenulida, Rhabditophora). J Morphol 249(3):171-194. doi:10.1002/jmor.1048

Hori I (1982) An ultrastructural study of the chromatoid body in planarian regenerative cells. J Electron Microsc 31(1):63-72

Kulaev IS, Vagabov VM (1983) Polyphosphate metabolism in microorganisms. In: Rose AH, Morris GJ, Tempest DW (eds) Advances in microbial physiology, vol 24. Academic Press, London, pp 83-171

Ladurner P, Rieger R, Baguñà J (2000) Spatial Distribution and Differentiation Potential of Stem Cells in Hatchlings and Adults in the Marine Platyhelminth Macrostomum sp.: a bromodeoxyuridine analysis. Dev Biol 226(2):231-241. doi:10.1006/dbio. 2000.9867

Larsson K, Jondelius U (2008) Phylogeny of Catenulida and support for Platyhelminthes. Org Divers Evol 8(5):378-387. doi: 10.1016/j.ode.2008.09.002

Moraczweski J (1981) Fine structure of some Catenulida (Turbellaria, Achoophora). Zool Pol 28:367-415

Noreña-Janssen C, Faubel A (1996) Myoretronectes paranaensis n. gen. et sp., a new freshwater genus of the family Retronectidae (Turbellaria, Catenulida) from the Paraná, Argentina. Hydrobiologia 330(2):111-118. doi:10.1007/bf00019999

Ott JA, Rieger G, Rieger R, Enderes F (1982) New mouthless interstitial worms from the sulfide system: symbiosis with prokaryotes.
PSZNI Mar Ecol 3(4):313-333. doi:10.1111/j.1439-0485.1982. tb00282.x

Ott JA, Novak R, Schiemer F, Hentschel U, Nebelsick M, Polz M (1991) Tackling the sulfide gradient: a novel strategy involving marine nematodes and chemoautotrophic ectosymbionts. PSZNI Mar Ecol 12(3):261-279. doi:10.1111/j.1439-0485.1991.tb00258.x

Peter R, Gschwentner R, Schürmann W, Rieger R, Ladurner P (2004) The significance of stem cells in free-living flatworms: one common source for all cells in the adult. J Appl Biomed 2:21-35

Philippe H, Brinkmann H, Copley RR, Moroz LL, Nakano H, Poustka AJ, Wallberg A, Peterson KJ, Telford MJ (2011) Acoelomorph flatworms are deuterostomes related to Xenoturbella. Nature 470(7333):255-258. doi:10.1038/nature09676

Rieger R (1981) Morphology of the Turbellaria at the ultrastructural level. Hydrobiologia 84(1):213-229. doi:10.1007/bf00026183

Rieger R, Tyler S, Smith JPSI, Rieger G (1991) Platyhelminthes: Turbellaria. In: Harridson FW (ed) Microscopic anatomy of invertebrates: Platyhelminthes and Nemertinea, vol 3. WileyLiss, New York, pp 7-140

Rohde K (2001) Protonephridia as phylogenetic characters. In: Littlewood DTJ, Bray RA (eds) Interrelationships of the Platyhelminthes. Taylor \& Francis, London, pp 203-216

Southward E, Schulze A, Gardiner S (2005) Pogonophora (Annelida): form and function. Hydrobiologia 535-536(1):227-251. doi: 10.1007/s10750-004-4401-6

Sterrer W, Rieger R (1974) Retronectidae - a new cosmopolitan marine family of Catenulida (Turbellaria). In: Riser N, Morse M (eds) Biology of the Turbellaria. McGraw-Hill, New York, pp 63-92

Tyler S, Hooge M (2004) Comparative morphology of the body wall in flatworms (Platyhelminthes). Can J Zool 82(2):194-210. doi: 10.1139/z03-222

Woyke T, Teeling H, Ivanova NN, Huntemann M, Richter M, Gloeckner FO, Boffelli D, Anderson IJ, Barry KW, Shapiro HJ, Szeto E, Kyrpides NC, Mussmann M, Amann R, Bergin C, Ruehland C, Rubin EM, Dubilier N (2006) Symbiosis insights through metagenomic analysis of a microbial consortium. Nature 443(7114):950-955. doi:10.1038/nature05192 